This is a self-archived version of an original article. This version may differ from the original in pagination and typographic details.

Author(s): Lähdesmäki, Tuuli

Title: Politics of belonging in Brussels' European Quarter

Year: 2020

Version: Accepted version (Final draft)

Copyright: (c) Taylor \& Francis, 2019

Rights: In Copyright

Rights url: http://rightsstatements.org/page/lnC/1.0/?language=en

Please cite the original version:

Lähdesmäki, T. (2020). Politics of belonging in Brussels' European Quarter. International Journal of Heritage Studies, 26(10), 979-997. https://doi.org/10.1080/13527258.2019.1663237 
FINAL DRAFT: Tuuli Lähdesmäki (2019): Politics of belonging in Brussels' European

Quarter, International Journal of Heritage Studies, DOI: 10.1080/13527258.2019.1663237

\title{
Politics of Belonging in Brussels' European Quarter
}

\author{
Tuuli Lähdesmäki
}

Department of Music, Art and Culture Studies, University of Jyväskylä, Jyväskylä, Finland

Postal address: Department of Music, Art and Culture Studies, P.O. Box 35, FI-40014

University of Jyväskylä, Finland

Tel: +358048053839

E-mail: tuuli.lahdesmaki@jyu.fi

ORCID: 0000-0002-5166-489X

Tuuli Lähdesmäki (PhD, DSocSc) is a Senior Researcher and an Adjunct Professor working in the Department of Music, Arts and Culture Studies, University of Jyväskylä (JYU), Finland. Lähdesmäki currently leads a research project 'Legitimation of European Cultural Heritage and the Dynamics of Identity Politics in the EU' (EUROHERIT), funded by the European Research Council. She is also leading JYU's consortium partnership in a research project 'Dialogue and Argumentation for cultural Literacy Learning in Schools' (DIALLS), funded from the EU's H2020 Programme. In addition, she is one of the three PIs in JYU's research profiling area 'Crises Redefined: Historical Continuity and Societal Change' (CRISES). Lähdesmäki's research record includes over 100 scholarly publications published e.g. in International Journal of Heritage Studies, European Journal of Cultural Studies, International Journal of Intercultural Relations, European Urban and Regional Studies, and European Societies. She is a co-editor of Politics of Scale. New Directions in Critical Heritage Studies (Berghahn's Books, 2019).

\section{Abstract}

The European Union (EU) has been criticised for a lack of imageries and sites of memory that nation-states have traditionally utilised in their identity-building. The EU, along with other actors, has responded to this iconographic deficit with memory and heritage initiatives and branding campaigns. This article explores how this deficit is dealt with in the European Quarter in Brussels by enlivening it through cultural regeneration and creating narratives that link 
Europe's and the EU's past with the present. The article utilises hermeneutic phenomenological approach combining observation and interpretation of diverse place-making practices, such as monuments, memorials, public artworks, history plaques, and naming of administration buildings, with close reading of the EU's marketing and promotional material. It examines how a feeling of belonging to Europe and the EU is advanced in the Quarter and how it is sought to be turned into a European collective place. The article indicates how the Quarter's politics of belonging ignores various layers of meanings related to its history and present. The Quarter's invitation to belong is selective as its narratives focus on male actors and ignore colonial references and today's multi-ethnic reality in the neighbourhood.

Keywords: place-making; politics of belonging; collective place, European Union; Brussels; European Quarter

\section{Introduction}

Since the Maastricht Treaty the European Union (EU) has been increasingly interested in promoting the perception of Europe as a common cultural area and strengthening Europeans' feeling of belonging to it. Through various memory and heritage initiatives, construction projects, and branding campaigns, the EU has sought to influence Europeans' views, notions, and feelings about the EU by framing the ideas of Europe and the EU with culture and concretizing these ideas by attaching them to physical environments and locations. In this article, I examine how the site of the core EU institutions in Brussels, the European Quarter, is constructed as a particular European site of significance and memory-a European collective place-by the means of place-making and selected historical narratives that seek to link Europe's and the EU's past with the present.

The attempts to turn the European Quarter into a European collective place are related to a broader framework of economic, political, social, and humanitarian crises with which the EU has been struggling for the past years. Moreover, scholars have long perceived that the EU is struggling in an identity crisis (e.g., Hoffmann 1994; Weiss 2002; Jenkins 2008). This identity crisis centres on the difficulty of defining what Europe is, what and who belong to it, who Europeans are, and which elements a European identity or identities could or should be based 
on in a Europe filled with diverse political, material, and symbolic divisions and distinctions (Jenkins 2008).

The EU's attempts to tackle its identity crisis face various challenges. Nations and states have commonly used (and still use) affective elements, such as 'distinctive buildings, monuments, artworks, and other symbols that might make it intelligible and compelling on a visual level' (Pearson 2013, 637; see also Wintle 2009), to build their identities and strengthen their selfimage and self-understanding. The EU does not have visual imageries or symbolic elements similar to those of nation states and has therefore been perceived as suffering from an 'iconographic deficit' (Koolhaas 2004; Oittinen 2007; Pearson 2013), a 'symbolic deficit' (Passerini 2003; Perchoc 2017), or a 'memory deficit' (Perchoc 2017). The challenges encountered in the EU's identity crisis are further complicated by the EU's attempts to construct the idea and image of Europe and a European identity with the very same symbolic elements utilised in creating and strengthening national and regional identities in Europe (Smith 1992; Jenkins 2008).

The EU's attempts to generate feeling of belonging to Europe and the EU as well as to advance inclusion and social unity in Europe are interpreted in this article as the EU's politics of belonging. Narratives of a European past, heritage, and memory are its core tools. This EU's 'move to history', as it has been called in literature (Prutsch 2013,36), is at the same time a highly future-oriented project: narrations of the past and attempts to foster a common memory and heritage in Europe function as building blocks through which the EU seeks to create a particular image of itself and justify certain politics. The goal of the EU's efforts is, as Patel $(2013,2)$ writes, to 'win the hearts and minds_-and not just the hands and muscle_-of the European citizens'. Through narrations of a European past, heritage and memory, the EU seeks to affect people's emotions and make them feel more European and connected to Europe, the EU, and other Europeans (Lähdesmäki 2017a).

The EU's leading administrative bodies - the European Commission (EC) and the European Parliament (EP) - are both very aware of the EU's identity crisis and iconographic deficit and have tried to respond to them in their actions. One of the key sites in which these actions are concretised is the European Quarter in Brussels. The EU, alongside the Belgian national leaders, the Brussels-Capital Region, the local tourist agency, and other actors, has launched several measures in the 2000s to strengthen the image of Brussels as the capital of the EU. 
These measures focus on the European past, memory, and heritage and their connections to today's Union, and the manifestation of these connections in situ in Brussels.

I have regularly visited the European Quarter and witnessed its rapid transformation: old buildings are being demolished and new ones constructed for the EU's administrative bodies; new public spaces are being created between the EU office buildings; new information boards and history plaques are erected; and new EU exhibition spaces and exhibitions are being opened. The data of this article are based on my hermeneutic phenomenological observations and interpretations of diverse place-making practices in the European Quarter, as well as exploring the EU's official information and promotional material dealing with it. Through this data, I scrutinise the multimodal construction of place as a critical tool to assess how politics of belonging are formed in Brussels. My research questions are: With what place-making practices is the past affixed to the European Quarter? How does the European Quarter invite people to belong to Europe and to the EU? To whom is this invitation addressed and who are excluded? What are the implications of the Quarter's politics of belonging?

\section{Growing scholarship on the EU's memory production}

During the past two decades, scholarship on the EU's identity, memory, and cultural politics has broadened extensively and adopted various theoretical and methodological approaches. Already Shore's (1996, 2000) and Shore and Wright's (1997) seminal studies indicated how culture is given multifaceted instrumental value in the EU governance and how the cultural sector has been used as a channel of power in economic and political EU integration. In scholarship, this process has been conceptualised as 'governmentalization of culture' (Barnett 2001), referring to the EU's attempts to make culture more governable and simultaneously a target and instrument of EU social-policy objectives. It has also been described as the 'cultural significance of Europeanization' (Delanty 2005), referring to the EU's emphasis on the cultural specificity of Europe in its policy rhetoric and attempts to build a European identity through culture.

Several scholars (e.g., Littoz-Monnet 2012; Macdonald 2013; Calligaro 2013, 2015; Niklasson 2016, 2017) have recently focused their research on the 'growing European infrastructure of memory production' (De Cesari 2017, 19). Moreover, scholars have been interested in how the 
EU is 'staging Europe' and how it is itself 'a product of staging', as Krumrey (2018) notes. The Union is trying to put forth a cultural history and memory of European integration that deal with often neglected aspects in its history: the Union's own protocols, ceremonies, symbols, and image of itself (Krumrey 2018, 5). Indeed, the EU's own symbolic representation is in the very heart of the real business of its politics (Krumrey 2018, 6; Manners 2011).

The EU has often been criticised for utilizing in its identity and memory politics means borrowed from nation-states and their nationalist agendas and, thus, failing to serve the goals of an inclusive trans- or post-national community (Shore 2000, 2006; De Cesari 2017). Even though the EU's own marketing discourses seek to promote post-national visions of Europe and Europeans, the existing and widely utilised constructions of European memory often depart, and even quite radically as De Cesari $(2017,20)$ notes, from those visions. This article indicates how the 'national order of things' Malkki $(1992,1995)$ functions also in the European Quarter, though the order is seemingly being blurred by the discourse of integration and the emphasis of shared European past, heritage, and values.

The history of Brussels' urban planning and the development of the European Quarter as a part of it has been explored in various studies (e.g., Beaten 2001; Hein 2004, 2006; Romańczyk 2012; McNamara 2015; Perchoc 2017). They display Brussel's transformation and construction as the EU's capital city as a complex, altering, and unstructured process, in which various actors have participated. The studies (Pearson 2013; Settele 2015; Kaiser 2017; Lähdesmäki 2017b; Eckersley 2018) on the exhibitions of the EP's visitor centre (Parlamentarium) and history museum (the House of European History) emphasise their fragmentary and selective view of the European past and present and the challenges to 'include exclusion in the official memory' (Settele 2015, 405), such as histories of migrants, colonised, and marginalised people, to the European narrative. Kaiser $(2017,531)$ notes how the exhibition narrative in the House of European History focuses on narrowing down the gap between Western and Eastern European memories at the expense of other forms of spatial fragmentation and divisions. Similarly, Perchoc's (2017) research on historical narratives at the European Quarter identifies the East-West reunification of Europe as the main narrative of the Quarter, along with the stories of the EU Founding Fathers and the continuity of European cultural elements related to mythology, and Europe's history before the modern era (cf. Sierp 2014; Lähdesmäki 2017b). 
Perchoc (2017) criticises the European Quarter for a lack of ordering and emplotment that would create a strong narrative for the EU, strengthen inclusion, and communicate moral lessons. Instead of any 'given' emplotment, I am interested in how the Quarter invites people to belong to Europe and the EU by bringing to the fore selected narratives from the European past and linking them to Europe's present and by turning meaningless spaces into meaningful places (cf. Donohoe 2014, xii) where people are expected to spend time, learn, and feel included.

\section{Data and methods}

Guided by my general interest in the EU's attempts at 'staging Europe' and creating narratives about it, I chose to observe the European Quarter holistically. I have wandered around the Quarter and observed its environment of monuments, artworks, buildings, information and history plaques, outdoor exhibitions, creation and regeneration of public spaces, constructions projects, and the overall transformation of the neighbourhood. I have entered sites that are accessible by visitors and taken with me all information and promotional material (books, booklets, brochures, leaflets, etc.) those sites offer free to their visitors. My interest in the European Quarter has focused on place-making practices implemented after Brussels was established in the 1960s as one of the three official locations for European institutions.

I have also observed people around me: how other people move and act in the Quarter and how their movement participates in making the site a collective place. Especially the touristic movement around the Quarter-visiting it with a primary interest in seeing and experiencing the capital of the EU-constructs the particularity and collectiveness of the place. I want to emphasise, however, that the category of a tourist/visitor is fluid. The Quarter is filled with people, such as tourists; school classes visiting it as a part of their education; EU officials; people whose work is related to the EU institutions or serving people at the Quarter; researchers; lobbyists; representatives of media; construction workers; and people living in the neighbourhood, whose roles vary and metamorphose.

During my visits in 2014 and 2016-2019, I have documented my observations by taking photographs and making notes. My data also includes the EU's printed information and promotional material and websites targeted at visitors to the Quarter. The EU's and Brussel- 
Capital Region's documents regarding the development of the area offer contextual information for the study. Table 1 summarises the data used in this article.

Table 1. Data categories and frequencies.

Methodologically, my research is based on hermeneutic phenomenological exploration of the European Quarter as a space that is constructed and regenerated into a collective place that seeks to transmit post-national narratives and memories of Europe and the EU and invites people to feel a sense of belonging. In practice, this approach has meant grounding my exploration on one of the core assumptions of phenomenology: people and environment compose an indivisible whole (Seamon 2000, 2002). Indeed, most phenomenological studies on space aim at understanding the ways in which environment both shapes people's actions and relationships in space and reciprocally becomes shaped by them (e.g., Tilley 1994; Bender 1998). Moreover, a phenomenological approach to space commonly emphasises how space engages 'sedimented layers of meaning by virtue of the actions and events that take place in them' (Tilley 1994, 78). At the core of the phenomenological method is the researcher's openness to the research phenomenon and 'to allow it to show itself in its fullness and complexity through her own direct involvement and understanding ... through firsthand, grounded contact with the phenomenon as it is experienced by the researcher' (Seamon 2002, n.p.). My holistic observation of the European Quarter has been based on this kind of openness to its means and modes of being a collective place as well as on its invitation to belong to and through it.

This observation is not detached from my interpretation of the narratives and meanings that the place seeks to tell me and others moving in it. Stemming from a long tradition of combining hermeneutics with phenomenology (e.g. Heidegger 1962; Ricoeur 1981), I recognise how the creation of the European Quarter is also a linguistic practice intertwined with various narrative, discursive, and textual meaning-making modalities. Also my own non-linguistic observations and experiences 'come to language' in the process of interpretation and search for meaning (Ricoeur 1981). The hermeneutic understanding of the Quarter is strengthened in my research through the interpretative close reading of the texts placed in the area, as well as texts dealing with it in the diverse informational and promotional material. 
The chosen methodology reflects my notion of place in this article. Although the study focuses on a physical site, its meanings are perceived as constructed not only through visual and spatial elements in situ but also through discursive and narrative layers provided in information plaques, brochures, leaflets, and websites. My take on place, thus, follows a long scholarly tradition of socially orientated approaches to space, in which its different aspects, such as space as perceived, conceived, and lived (Lefebvre 1991) or as concrete, abstract, real, and imagined (Soja 1996), are understood as merged. In the European Quarter, space is signified as a particular collective place through physical place-making practices and narrating its meanings in texts. Hermeneutic phenomenology serves, thus, as a useful methodological approach for understanding the construction of place and the transformation of space to place.

\section{Constructing a European collective place}

In my analysis, I utilise the ideas of place-making, collective places, and politics of belonging as conceptual tools to describe and interpret meanings in the European Quarter. These concepts are linked in various ways. Smith $(2006,75)$ has noted how '[h]eritage, particularly in its material representations, provides not only a physical anchor or geographical sense of belonging, but also allows us to negotiate a sense of social "place" or class/community identity, and a cultural place or sense of belonging.' Place has, thus, a double function in gluing together communities and their memories and heritages: It serves as a material location for a feeling of place-beloningness (Antonsich 2010) as well as for finding one's social and cultural place in a community. Material representations of heritage and memory and places marked with references to the past are approached, in this article, through this double function. They offer (some) people an invitation to belong to the place and to feel socially and culturally included in the community brought forth and framed by these representations. Therefore, the relationship of place and its invitation to belong is not seen here only as a subjective matter, an individual's capacity or the will to belong. It is seen as an intersubjective possibility that the places and the representations of heritage and memory in them may, however, preclude some people from feeling included. This view resonates with Casey's (2000) notion on the placememory relationship. For him, 'place is selective for memories: that is to say, a given place will invite certain memories while discouraging others' (Casey 2000, 189). On a collective level, this kind of place-memory relationships ultimately rely on intersubjectivity. As Donohoe (2014, Xv) notes, 'collective places' are not only shared spaces that many people use, visit, or 
inhabit but intersubjectively engaged places of collective memories and shared narratives that enable people to feel belonging. It is this intersubjective collectiveness of place that I am interested in exploring in the European Quarter. My methodological approach supports this interest as 'body-based intersubjectivity' can be perceived as the 'birthplace of meaning' (Johnson 2007, 51; Schorch 2014, 26). Phenomenological observation combined with hermeneutic interpretation of places can produce an understanding of their intersubjective nature and collective meanings.

The concept of belonging has been much theorised in scholarship (e.g., Antonsich 2010; YuvalDavis 2004, 2006). It is a concept that includes both personal and intimate feelings and experiences and a shared and collective dimension of participating in a broader group or community. Stemming from this duality, Yuval-Davis (2006) makes a distinction between psychological and political belonging, while Antonsich $(2010,645)$ sees the discussions on belonging as structured around two dimensions: 'belonging as a personal, intimate feeling of being "at home" in a place (place-belongingness) and belonging as a discursive resource which constructs, claims, justifies, or resists forms of socio-spatial inclusion/exclusion (politics of belonging)'. In this article, I approach the feeling of belonging and the politics of belonging as two inevitably intertwined aspects. Here, the politics of belonging is about an actor, such as the EU institutions, who uses selectively discursive resources, such as narrations of the past, memory, heritage, and symbols, to create or strengthen a particular feeling of belonging. This feeling of belonging is in principle spatial and attached to physical and/or symbolic places. Place-making functions as a powerful tool in the politics of belonging (Lähdesmäki 2019) as the place is an active constituent in the process of belonging (Bennett 2012,44).

\section{Affixing the European past to the European Quarter}

The attempts to strengthen the symbolic meaning of Brussels as the capital of the EU aim to construct the European Quarter as a collective place. In this collective place both material and non-material dimensions of memory, as well as the real and imagined past of the EU, entangle. Next, I discuss the core place-making practices used in these attempts by introducing exemplars (see Benner 1994), which I interpret as having a central role in affixing the European past into the narrative of the Quarter. I identified six place-making practices through my observations in situ and interpretation of the data within the context of previous literature (see Seamon 2000). 
Following Ricoeur's $(1981,123)$ view on perception as 'already the seat of a work of interpretation', I do not separate in the analysis my observations from my attempts to understand their meanings. In line with a hermeneutic take on environment, my observation of the European Quarter and its place-making practices is merged to the interpretation of 'things' in the Quarter and how they are related to other things in the webs of particular lives and places' (Mugerauer 1985, 59).

One of the most traditional means of commemorating the past in the present is to erect monuments for past heroes and their achievements. Erecting monuments is always an act of power and an ideological manifestation of ideas, deeds, and beliefs that those erecting the monument see as worth cherishing in the present and transmitting to the future (Choay 2001). In the European Quartier, the place-making practice of monumentalizing focuses on Robert Schuman, commonly called the Founding Father of the EU in the EU's promotional texts. His monument, a large stone that states in four languages (French, Dutch, German, and Italian) 'promoter of European unity', was first erected in the Parc du Cinquantenaire but later moved to a central place in the European Quarter-in front of the EC's headquarters, the Berlaymont. In addition, in 1987 a bronze bust of Schuman was unveiled at the gate of the Parc du Cinquantenaire within sight of the Berlaymont. The text on the pedestal of the bust says 'future of Europe' in French. Through these monuments, Schuman is literally raised on a pedestal as the EU's core Great Man and introduced as the hero whose commemoration is seen important to foster at the 'authentic' site of his achievements. The texts on the monuments pinpoint the community for whom Schuman is shown as having worked. In both monuments, this community is Europe-not the EU. The monuments, thus, blur the distinction between the EU as a political institution and Europe as a broader socio-spatial entity.

Secondly, a European collective place is created in the European Quarter by preserving authentic remnants or traces of the past. This common western practice of preservation is implemented in the Quarter through imported authenticity. The Quarter hosts three pieces of the Berlin Wall, placed next to the EC and the EP's buildings, where they function as both memorials and aestheticized sculptures (Fig. 1). The pieces belong to a series of ten wall sections that were displayed in Brussels on Place du Luxembourg in 2009 to commemorate the 20th anniversary of the fall of the Berlin Wall (Regout 2014). Three pieces remained in Brussels, two of them acquired by the EP and one by the EC, and after a few years they found their current locations in the Quarter. All the pieces are fitted with information plaques. The 
piece next to the Berlaymont, representing John F. Kennedy and an American flag, is museumised by protecting it with glass covers and surrounding the piece with more detailed and illustrated stands about the history of the Berlin Wall and political transformations in Europe. Through its visuality, the piece underlines the EU's transatlantic relations and the US's role in Europe's post-war history.

Figure 1. Piece of Berlin wall in Brussels. Photo: Tuuli Lähdesmäki.

A common means of building a collective memory of a community-particularly in national myths-is to cherish past collective victories and conquests and to mourn the victims and losses caused by their pursuit. These victories, conquests, and losses are commonly mythologised in commemorative narratives and representations (Boime 1987; Schwartz 1990). Commemoration that is concretised to events, memorials, and exhibitions in particular locations adds a spatial dimension to the cherishing of victories and the mourning of losses: the symbolism and meanings of the commemoration and the place entwine-and the place itself can be mythologised as a core venue of collective myths. Therefore, commemoration is also about place-making.

All three pieces of the Berlin Wall in the European Quarter seek to build a European collective memory by appealing to victories, conquests, and losses. While building a collective memory, the pieces also signify the EU as an important actor in these victories, conquests, and losses and draw the European Quarter as one of their main venues. The piece next to the Berlaymont was unveiled in 2014 to commemorate the 25th anniversary of the reunification of Germany. The information stands next to the piece emphasise the history of European integration and its major steps through the Eastern enlargement of the Union in 2004 and 2007 and by opening the enlargement to the Balkans in 2013. Similarly, the piece in a park next to the EP's building connects the piece with the EU's integration process. According to its plaque: 'The fall of the wall, 9.11.1989, made possible the unification of Eastern and Western Europe within the European Union on May 1, 2004' (translation from French by TL). The fall of the Berlin Wall is narrated, thus, as a victory for the EU.

An information plaque on the other wall piece in front of the Hemicycle, the EP's chamber, also attaches the piece to the EU's European project. In addition to unification and integration, the plaque on the piece states that it is set 'in honor of the victims of dictatorial regimes and as 
a symbol of the European peoples' commitment to peace, freedom and democracy'. The plaque emphasises the core values that the EU commonly promotes as European in its policy discourse and, thus, draws the EU as the antagonist opposite of its antipode, dictatorships. The mourning of victims and promoting the EU's core values are also linked in a memorial that commemorates the gathering of Europeans in Brussels, in 2002, fighting to eradicate extreme poverty. In the text of the memorial placed between the EP's buildings in the pedestrian area called Esplanade Solidarność, extreme poverty is addressed as a human rights issue.

In addition to mourning the victims of dictatorships and 'hunger, ignorance and violence', the European Quarter offers a venue for mourning victims of terrorist attacks. A memorial, with a description not specifying to which victims of what attack it is dedicated, was inaugurated between Schuman roundabout and his memorial bust in 2017, a year after Islamist suicide bombings in Brussels (Fig. 2). Through this memorial, terrorism becomes included in the narrative of Europe's past and current struggles. Through topics of poverty and terrorism, the mourning in the European Quarter receives a global dimension. The global dimension and the themes of terrorism, mourning, and promoting peace intersect in the memorial of the former Israeli Prime Minister Yitzhak Rabin. The memorial stone, inaugurated in 2005 with the planting of an olive tree, discloses two meaningful narrative elements: Rabin was awarded the Nobel Peace Prize in 1994 and 'assassinated by an extremist' (translation from French by TL).

Figure 2. Jean-Henri Compère, Toujours Debout, the memorial for the victims of terrorist attacks, 2017, Brussels. Photo: Tuuli Lähdesmäki.

The fourth place-making practice and means of affixing the past to the present in the European Quarter is to name public spaces and buildings after historical actors or persons. The EP started the naming practice in 1999 (Perchoc 2017, 373). Naming that is not related to the already existing cartographic layers of the Quarter functions as an effective place-making tool that binds selected historical narratives to the urban setting. The names for the EP's office buildings underline the political history of the EU by drawing from politicians with different nationalities who have promoted European unification and integration. The names of PaulHenri Spaak, Altiero Spinelli, Willy Brant, and József Antall are visibly written above or near the doorways of these buildings. The bridge connecting the Brant and Antall buildings is named the Konrad Adenauer bridge. Moreover, the spaces inside the EP's buildings follow the same naming logic. The EP has previously occupied the Jacques Delors and Bertha von Suttner 
buildings, both named in 2006. Robert Schuman, has given his name to a roundabout and metro station in the centre of the Quarter already in the 1960s (Hein 2004, 141).

Naming buildings and public spaces after past politicians is a means to create and concretise a particular canon of the Great Men of the EU. This canon is extremely masculine, however, it includes some women who have had a particular role in the creation of the EU's narrative and memory as a peace project - a narrative that the EU has sought to emphasise since its early years (Mäkinen forthcoming). Bertha von Suttner, the first woman to be awarded the Nobel Peace Prize in 1905, suits this narrative well. Moreover, the square between EP's buildings was named Agora Simone Veil in 2011. As the first President of the EP, a feminist politician, and a Holocaust survivor, she represents the core values and political ideas promoted in the EU's political discourse: unification, equality, and the EU as a peace project. In 2017, Veil's life and political work was honoured at her square in a photo exhibition 'Conscience of a century'. It emphasised the EU's peace narrative by beginning the exhibition from an image of children in Auschwitz and ending with her quotation 'Europe had a duty to be an example of democracy and respect for human rights', illustrated with an image of Veil at the naming celebration of her Agora.

The naming of the EU buildings is related to the fifth place-making practice, setting up information plaques next to them and other significant sites in the Quarter. These plaques interconnect selected persons, past events, places, the history of the EU institutions, and the political discourse of the EU by including them in a coherent narrative. The links between past and present may even draw on imagined similarities between different millenniums, as the plaque next to the Charlemagne building-borrowing its name from the Boulevard Charlemagne_-indicates:

This building, which was the seat of the Council of the European Communities between 1971 and 1995, currently houses several directorates-general of the European Commission. Charlemagne (Herstal or Jupille 748? - Aix-le-Chapelle 814) become Kind of the Franck in 768. In 800, he was crowned emperor by Pope Leo III. His reforms in the area of religion and culture have been described as "Carolingian Renaissance". But his Empire was divided between his three grandchildren. The period of feudal fragmentation which marked the following centuries was followed by the division of Europe into rival nation-states. 
Charlemagne is often considered as an early inspirer of Europe, having unified a large part of Western Europe during his life.

On the plaque, Charlemagne functions as a channel for bringing one of the main enemies of the EU, rival nationalism and nation-states (cf. Lähdesmäki 2017b), as well as its core aim, unification, to the introduction of the building, and, thus, to link Carolingian Renaissance to the EU.

The European Quarter functions as an arena for various exhibitions. Some of these exhibitions are exhibited in public spaces next to the EU buildings and some in particular exhibition spaces (Parlamentarium, Station Europe, and the House of European History). Setting up museums, exhibition spaces, and exhibitions is the sixth place-making practice seeking to connect the Quarter to the imagined community of Europeans and establish its official memories. The exhibitions seek to enliven the Quarter, impact people's feelings, and make it more meaningful for them. This aim is explicitly stated in the exhibition 'How Brussels became the capital of Europe and how this area became Brussels' European Quarter', displayed in stands next to the Berlaymont. According to the exhibition stand: 'Knowledge of the history behind the buildings, squares, parks, monuments and street names will help give meaning and soul to the neighborhood and make it a more pleasant place in which to leave, work and stroll.' The means of place-making in the Quarter seeks to entwine informative and emotional dimensions. Through the exhibition spaces the European Quarter follows nation-states' common practice of manifesting the shared past and common historical and cultural roots at the administrative centre of the community.

Moreover, both the EC and the EP have their own art collections, and the EP even regularly organises public art exhibition in its premises. The collections can also be explored through the EC's online catalogue and the EP's online gallery. The EP has explicated that its aim is to collect and exhibit contemporary artworks that are 'representative of national art at a European level' (EP 2016). The idea of collecting art is borrowed from national parliaments, as the EP notes itself on its website (EP 2016). Without going further into the analysis of the contents of the above-mentioned exhibitions and exhibition spaces, the practice of exhibiting and museumising the community's past can be seen as a central element of its communal identitybuilding, familiar from nation-building projects in modern Europe-and beyond. 
The creation of a European collective place in the European Quarter relies on entwined narrative, emotive, and tactile dimensions of the above-described place-making practices. The communication discourses of the EU institutions-for example at the EC and the EP's websites - also seek to appeal to both the cognitive curiosity and emotions of the visitors to the Quarter and invite them to spend time and explore the history of Europe and the EU (often treated as the same entity) at the enlivened, renewed, or constructed sites. The Quarter and how it is promoted by the EU invites people to feel a sense of belonging to Europe but its invitation is selectively addressed. Next, I will focus my discussion on the invitation to belong in the Quarter and how this invitation, issued through the place-making practices in it, includes people to-but also excludes people from-engaging in the idea of Europe. The exploration of this invitation is based on my intertwined observations of the place-making practices in the Quarter and interpretations of them as its politics of belonging. My exploration, thus, relies on a constant dialectic movement between explanation and understanding and between interpretations of the parts of the Quarter's-its place-making practices—and the Quarter as a whole, as emphasized by Ricoeur's (1973) hermeneutics and applied in various hermeneutic phenomenological studies (e.g. Beck 2016; Victor and Barnard 2016; Simonÿ et al. 2018).

The creation of a European collective place in the European Quarter is a memory project that creates a history for the EU. This history reaches to the beginning of the economic and political integration in Europe-launched by the Treaty of Rome in 1957-but also includes narratives going further back in history and beyond the borders of the EU in spatial terms, as the exemplars of the Charlemagne building and the memorial of Rabin indicate. These narratives present the EU as a continuation of a long European (cultural) tradition by binding together historical narratives of Europe and the contemporary ideas, ideologies, political messages, and values promoted in the EU's policy discourses (Lähdesmäki 2016, 2017b; Perchoc 2017). The master narrative of peace and the EU as its manifestation reaches a global scale in the Quarter. The peace narrative's basis in the EU as well as its global address is exemplified in the plaque (renewed in 2012) next to a 'peace tree' in the Léopold Park planted in 1991 as part of the World Harmony Run. It says: 
This tree is dedicated to humanity's aspiration for World Peace. From man's inner realisation of peace, World Peace will grow and mankind will become a Oneness-World Peace-Family. In this process the oneness of the European nations is a significant achievement, therefore this tree is also dedicated to the United Europe.

In a similar manner, the sculpture Unity in Peace (2003), made to honour the European Year of People with Disabilities by a group of impaired children under the supervision of French artist Bernard Romain, addresses a global audience through multicoloured hands holding a globe and a dove. In the sculpture, though, the globe as a blue ball encircled by yellow stars is paralleled by the EU's symbolism (Fig. 3).

Figure 3. Unity in Peace, 2003, made under supervision by Bernard Romain, Brussels. Photo: Tuuli Lähdesmäki.

Although the European Quarter transmits a strong global - but Eurocentric - peace narrative and, thus, addresses people worldwide, the area's above-discussed place-making practices mainly focus on addressing EU citizens and their sense of belonging to the geographical union. EU citizens are addressed for example by bringing forth the Founding Fathers and other Great Men of the Union and their political achievements and merits; telling the story of the EU in the European historical and political context at the Parlamentarium, Station of Europe, and the House of European History; commemorating the 'birth' of the Union via the Treaty of Rome through a sculpture called European Citizens (Fig. 4) next to the Berlaymont; and focusing on EU symbolism as in the sculpture Europa, in which a female figure holds the symbol of the euro currency. The Quarter offers EU citizens various invitations to celebrate the memory of the EU community. The places addressing EU citizens are also those that appeal most to touristic visitors and school groups. People who queue to see exhibitions or Hemicycle and who take photographs of the EP's buildings and the sculpture Europa, are all participating in making these sites significant and shared through a common interest in them.

Figure 4. Susanne Boerner, European Citizens, commemorating the 60th anniversary of the Treaty of Rome, 2016-2017, Brussels. Figure on the right represents Jean Monnet. Photo: Tuuli Lähdesmäki. 
Besides an explicit pro-EU narrative promoted by the identified place-making practices, the European Quarter also issues an invitation for a critical exploration of the EU. Trying to be cautious over presenting any master interpretation of Europe's past, the House of European History aims to 'ask(s) questions about the continent's heritage of shared traditions and achievements, so that the visitor can explore different ways of thinking about Europe'. Through this approach, the museum seeks to encourage visitors 'to think critically about its [Europe's] past in order to engage in its future and present-day issues' (EP 2018, n.p.).

The most explicit invitation to belong in the European Quarter addresses the countries and people from the former eastern bloc. The Quarter's memory narrative focuses particularly on the attempts for unifying Europe and the struggle for democracy and human rights in divided Europe-especially the struggle for democracy and human rights in the totalitarian countries in Eastern Europe. This memory narrative is principally about extending the West in Europe or embedding Eastern European memory into Western European / the EU's. The narrative in the Quarter seeks to foster east-west unification of Europe and promote Western and Eastern Europeans' belonging to the same union. This attempt Europeanises regional and national political histories in Eastern European countries as a part of the story of the EU (cf. Delanty 2005; Lähdesmäki 2017b; Lähdesmäki, Kaasik-Krogerus, and Mäkinen 2019) and reveals and simultaneously maintains rather than leaves behind the existence of the East-West divide.

The history plaques in the Quarter, as well as the exhibitions introducing the functioning of the $\mathrm{EP}$, present the EU as a multinational and multilingual entity united within the EU and committed to shared EU values. Besides addressing individuals as members of a global community, the EU, or Eastern Europe, the European Quarter invites European peoples and nations to belong together in the EU. Signposts on buildings naming the EU institutions in all official EU languages participates in addressing peoples in Europe. Similarly, the monument for Slovenia's First EU Presidency, inaugurated in 2008 next to the Council's building, addresses European peoples: it includes the first line of Slovenia's national anthem, 'May all peoples thrive and prosper', in 23 languages.

The emphasis on peoples and nations of the EU member states is the most explicit element in the narrative of diversity in the European Quarter. Approaching diversity only through them offers, however, a very narrow and limited point of view about it. The Quarter includes some modest gestures that address other kinds of differences. Besides Unity in Peace, disabled 
people were recognised through an image of a woman with Down syndrome amongst the visual installations of the outdoor exhibition 'This time I'm voting' at the Agora Simone Veil in 2019. Moreover, sexual and gender minorities were addressed in the Quarter in 2019 through a large rainbow flag painted on the street between the Council and the EC's buildings.

\section{Excluded from the invitation to belong}

The narration of the past always reveals some selected layers of meaning while ignoring or pushing others to the background. The choices in this selection process, as well as in addressing the narrative to selected groups of people, are core elements in the politics of belonging. In this final part of my analysis, I explore the invisible and silent subjectivities in the European Quarter. This exploration stems from my observations of the absent brought forth by my interpretations of the Quarter's invitation to belong. This kind of analytic movement between 'figures' and 'backgrounds' and their visible and invisible phenomena is crucial in phenomenological research (e.g., Merleau-Ponty 1968). Indeed, '[a]ny meaning which becomes "visible" or "speaks" to us does so only insofar as it is defined against this "invisible" or "silent" background of perceptual, reflective, and historical relationships', as Quinn (2009, 12) notes. I approach here the simultaneous visibility and invisibility of figures and meanings (Dahlberg 2006) as simultaneous inclusion and exclusion of subjectivities in the European Quarter. While some people are included in the European Quarter's invitation to belong, others remain silent, invisible, missed, and, thus, excluded. The analysis, thus, shows how environment shapes people's relationships in space (Tilley 1994).

While emphasizing the European layer of meanings, place-making practices in the European Quarter bypass various former as well as current global, national, and local meanings. Some local historical layers of the Quarter, such as its 19th century residential and bourgeois neighbourhoods, are quickly disappearing. This layer does not have any major role in the EU's own history narrative. Moreover, the European Quarter does not address the colonial past nor the reality of non-European immigration in and nearby the Quarter. Indeed, the EU's narrative about peace, democratic development, and solidarity focuses narrowly on dismantling the totalitarian regimes in Europe and unifying Eastern and Western Europe (Cesari 2017, 20). 
The plaques in the Quarter and the EU's brochures and websites remain silent about colonial references in the area, even though the centre of the European Quarter is closely connected with the colonial legacy — particularly through the Belgian king Leopold II, whose reign is today commonly perceived as symbolizing the colonial exploitation of the Congo Free State. Leopold has given his name to the Quarter that hosts the EP's headquarters. The whole complex of the headquarters is called Espace Léopold. Behind it is Léopold Park, which hosts the House of European History. The Berlaymont is located close to the Parc du Cinquantenaire, built to commemorate the 50th anniversary of the independent state of Belgium. Its building was funded through exploitation of natural resources from Congo (Hochschild 1998, 294). In the park, just a stone's throw from the bust of Schuman, is a monument for Belgian pioneers in Congo set up in 1921 to commemorate the explorers, missionaries, and soldiers who worked for its colonization.

In the corner of the park, just behind this monument, is the oldest mosque in Brussels, hosting also the Islamic and Cultural Centre of Belgium. After the terrorist attacks in Brussels in 2016 - one of them located in the heart of the European Quarter - the mosque and the Center have been under the supervision of the Belgian authorities. This supervision has also extended to the neighbouring commune of Schaerbeek, inhabited by a mixed population that includes a lot of Muslims, with the largest share of Moroccan origin. The current multicultural and multireligious reality of the nearby districts (such as Matongé, inhabited by a large community of people of African origin) and the recent immigration to the area do not either have any role in the EU's narrative in the Quarter. The representations of Europeans in the European Quarter emphasise their racial whiteness. In the sculpture European citizens, discussed earlier, all twelve figures are white and lacking all markers of racial or religious minority identities. Similarly, the exhibition 'This time I'm voting' represents only white people without a scarf, except in one picture illustrating migration. The caption of the that picture, depicting five people of whom the closest is a woman wearing black clothes and a scarf, approaches migration as a security issue both from the point of view of migrants and Europe's external borders. The invitation to belong in the Quarter, thus, excludes newcomers to Europe.

The masculine narrative of the European Quarter continues in the Léopold Park, in which plaques tell the history of the park as a former location of five scientific institutions dedicated to medicine, physics, and economics. Images on the history plaques in the park, as well as those in front of the EU institutions, illustrate the masculine canon of science and politics. In these 
images, men are depicted at work or in their work environment. The only female hero in the Quarter, Simone Veil, is depicted in her memory plaque through an artistically aestheticized portrait. Female figures depicted in the sculptures in the Quarter have a mythical function, such as naked princess Europe on the back of the bull in Léon De Pas' L'Europe en avant, or a decorative function, such as cheerful women and girls in the René Julien's The Muses (Fig. 5).

Figure 5. René Julien, The Muses, 1996-1998, detail, Brussels. On the right, the Europa building opened in 2017. Photo: Tuuli Lähdesmäki.

\section{Conclusions}

This article has shown how the European Quarter's memory project is selective, picking events and incidents from the past that fit into the narrative and image that the EU and other actors in Brussels wants to tell to Europeans. This narrative seeks to build inclusive belonging to Europe and the EU and to enhance connectedness among EU citizens. Its emphasis on selected master narratives-building peace in Europe, unification after the collapse of the Iron Curtain, and working for European integration-hides, however, various less-discussed conflicts and divisions and current struggles and tensions in Europe that have an impact on people's feelings of belonging and whom are represented and considered as belonging to Europe. The placemaking practices and politics of belonging in the Quarter excludes from it various people in Europe, such as new EU citizens, non-EU citizens, and newcomers. The Quarter's invitation to belong focuses on male actors and ignores colonial references and today's multi-ethnic reality both in the neighbourhood and throughout Europe.

The creation of a European collective place in the European Quarter reflects the challenges that the EU has faced and is currently facing. For the EU, these challenges are not, however, only problems to be tackled, but simultaneously also a window of opportunity through which the Union can implement its European project. As Jenkins (2008) notes, the lack of consensus on the idea of Europe is not a state of emergency in the EU but rather a normality that even functions as a strength for the Union. Challenges, crises, and a lack of consensus enable and justify the EU acting to increase stability and consensus in the union. Similarly, Eder (2014) notes how diverse crises, stemming from the unworking political, economic, and structural systems of the union, create possibilities to invent a European community in a new way. A part 
of this invention is ""people-making" beyond the national container' (Eder 2014, 227), which seeks to attach the idea of belonging to a broader and more abstract European community. The politics of belonging in the European Quarter utilises in its 'people-making' means that are common in nation-building projects. This politics draws on the invention of-or borrowing of - cultural symbols, a shared heritage, narratives from the past, a canon of heroes, and common values, and locates them in a space that functions as their (new) home.

The studies on the creation and development of EU symbolism, covering for example the visual aesthetics of the EU flag, audible aesthetics of the official EU hymn, and visual-spatial aesthetics of the architectural motifs on euro banknotes (Delanty and Jones 2002; Wintle 2004; 2009; Theiler 2005; Fornäs 2011, 2012; Pearson 2013), reveal the challenges of the EU as grounded on states and nations but simultaneously seeking to advance the post-national image of itself by transcending 'the national'. The EU's politics of belonging is about constant balancing between the acknowledged similarities of nation-states' identity building practices and attempts to build a post-national political and value-based communality whose grounds differ from those of nation-states. The idea of place is central for this balancing. On the one hand, the above mentioned EU symbols or the lists of the EU's lofty values do not refer to any particular places. On the other hand, the EU is also utilizing in its politics of belonging places and sites in its member states as building blocks of the 'European'. For example, the EU actions of the European Capitals of Culture and the European Heritage Label suggest that the Union can have at least annually rotating 'cultural capitals' and heritage sites with European significance in multiple locations around Europe. The construction of the European Quarter indicates, however, that the actors in Brussels have not seen the placeless EU symbolism or the cultural actions placing the 'European' in different ways to multiple locations in Europe as adequate to cover the need for a core collective European place and a 'real capital' of the EU. The applied hermeneutic phenomenological method brought forth how the place-making practices and politics of belonging in the 'capital' of the EU and in the European Quarter as its symbolic heart are, however, limited in their ways of addressing people in Europe and dealing with the idea of being European.

\section{Acknowledgements:}

This work was supported by the Academy of Finland under Grant SA274295 (EUCHE). 


\section{References}

Antonsich, M. 2010. "Searching for Belonging - An Analytical Framework." Geography Compass 4(6): 644-659.

Barnett, C. 2001. "Culture, Policy and Subsidiarity in the European Union: From Symbolic Identity to the Governmentalisation of Culture." Political Geography 20(4): 405-426.

Beaten, G. 2001. "The Europeanization of Brussels and the Urbanization of 'Europe': Hybridizing the City. Empowerment and Disempowerment in the EU District." European Urban and Regional Studies 8(2): 117-130.

Beck, M., B. Martinsen, I. Poulsen, and R. Birkelund. 2016. "Mealtimes in a Neurological Ward: A Phenomenological-hermeneutic Study." Journal of Clinical Nursing 25(11-12): $1614-1623$.

Bennett, J. M. 2012. Doing Belonging: A Sociological Study of Belonging in Place as the Outcome of Social Practices. PhD thesis, the University of Manchester, the UK.

Bender, B. 1998. Stonehenge: Making Space. Oxford: Berg.

Boime, A. 1987. Hollow Icons: The Politics of Sculpture in Nineteenth-Century France. Kent: The Kent State University Press.

Benner, P. 1994. The tradition and skill of interpretive phenomenology in studying health, illness, and caring practices. In Interpretive Phenomenology, Embodiment, Caring, and Ethics in Health and Illness, edited by P. Benner, 99-127. Thousand Oaks, CA: Sage.

Calligaro, O. 2013. Negotiating Europe: The EU Promotion of Europeanness since the 1950s. New York: Palgrave Macmillan 
Calligaro, O. 2015. "Legitimation Through Remembrance? The Changing Regimes of Historicity of European Integration.” Journal of Contemporary European Studies 23(3): 330343.

Casey, E. 2000. Remembering: A Phenomenological Study. Bloomington: Indiana University.

Choay, F. 2001. The Invention of the Historic Monument. Cambridge: Cambridge University Press.

Dahlberg, K. 2006. “"The Individual in the World - The World in the Individual': Towards a Human Science Phenomenology that Includes the Social World." Indo-Pacific Journal of Phenomenology 6(1): 1-9.

Delanty, G. 2005. "The Idea of a Cosmopolitan Europe: On the Cultural Significance of Europeanization." International Review of Sociology 15(3): 405-421.

Delanty, G. and P. R. Jones. 2002. "European Identity and Architecture”. European Journal of Social Theory 5(4): 453-466.

De Cesari, C. 2017. "Museums of Europe: Tangles of Memory, Borders, and Race." Museum Anthropology 40: 18-35.

Donohoe, J. 2014. Remembering Places: A Phenomenological Study of the Relationship between Memory and Place. London: Lexington books.

Eder, K. 2014. "The EU in Search of Its People: The Birth of a Society out of the Crisis of Europe." European Journal of Social Theory 17(3): 219-237.

Eckersley, S. 2018. "Europe on Display: A Case Study.” Education, Heritage and Identities in Europe: Understanding Europe's Current Predicaments, 54-50. CoHere project, Newcastle University.

https://eu.bilgi.edu.tr/media/files/Education_Heritage_and_Identities_in_Europe_2018.pdf 
EP (European Parliament) 2016. Art Collection. Retrieved from http://www.europarl.europa.eu/art-collection/en/faq.htm

EP (European Parliament). 2018. House of European History. Brochure. Brussels: European Parliament.

European Quarter Fund. 2013. "Branding the European Quarter in Brussels - A European Quarter Fund initiative.” Retrieved from http://www.europeanquarter.eu/about-us.html

Fornäs, J. 2011. Signifying Europe. Bristol: Intellect Press.

Fornäs, J. 2012. "European Identification: Symbolic Mediations of Unity and Diversity." Global Media Journal 6(1).

Heidegger, M. 1962. Being and Time. Malden, USA: Blackwell Publishing.

Hein, C. 2004. The Capital of Europe: Architecture and Urban Planning for the European Union. Westport: Greenwood.

Hein, C. 2006. "In Search of Icons for a United Europe.” City 10(1): 71-89,

Hochschild, A. 1998. King Leopold's Ghost: A Story of Greed, Terror, and Heroism in Colonial Africa. New York: Mariner Books.

Hoffmann, S. 1994. “Europe's Identity Crisis Revisited.” Daedalus 123(2): 1-23.

Jenkins, R. 2008. "The Ambiguity of Europe.” European Societies 10(2): 153-176.

Johnson, M. 2007. The meaning of the body. Chicago, IL: University of Chicago Press.

Kaiser, W. 2017. "Limits of Cultural Engineering: Actors and Narratives in the European Parliament's House of European History Project." Journal of Common market Studies 55(3): $518-534$. 
Koolhaas, R. 2004. Content. Köln: Taschen.

Krumrey, J. 2018. The Symbolic Politics of European Integration: Staging Europe. New York: Palgrave Macmillan.

Lähdesmäki, T. 2016. "Politics of Tangibility, Intangibility, and Place in the Making of European Cultural Heritage in EU Heritage Policy." International Journal of Heritage Studies 22(10): 766-780.

Lähdesmäki, T. 2017a. "Politics of Affect in the EU Heritage Policy Discourse: An Analysis of Promotional Videos of Sites Awarded with the European Heritage Label." International Journal of Heritage Studies 23(8): 709-722.

Lähdesmäki, T. 2017b. "Narrativity and Intertextuality in the Making of a Shared European Memory." Journal of Contemporary European Studies 25(1): 57-72.

Lähdesmäki, T. 2019. “Taide, paikka ja kuulumisen politiikka EU:n Eurooppa-projektissa.” In Taide, paikka ja kuuluminen, edited by K. Hiltunen and N. Sääskilahti, 149-174. Turku: Eetos.

Lähdesmäki, T., S. Kaasik-Krogerus and K. Mäkinen. 2019. Genealogy of the concept of heritage in the European Commission's policy discourse. Contributions to the History of Concepts 14(1): 115-139.

Lefebvre, H. 1991. The Production of Space, trans. D. Nicholson-Smith. Oxford: Blackwell.

Littoz-Monnet, A. 2012 "The EU politics of remembrance: Can Europeans remember together?" West European Politics 35(5): 1182-1202.

Macdonald, S. 2013. Memorylands. Heritage and Identity in Europe Today. London: Routledge.

Malkki, L. 1992. "National Geographic: The Rooting of Peoples and the Territorialization of National Identity among Scholars and Refugees." Cultural Anthropology 7(1): 24-44. 
Malkki. L. 1995. "Refugees and Exile: From 'Refugee Studies' to the National Order of Things." Annual Review of Anthropology 24(1): 495-523.

McNamara, K. 2015. The Politics of Everyday Europe: Constructing Authority in the European Union. Oxford: Oxford University Press.

Mäkinen, K. (forthcoming). "Interconceptualising Europe and Peace: Identity Building in the European Heritage Label." In Dissonant Heritages and Memories in Contemporary Europe, edited by T. Lähdesmäki, L. Passerini, S. Kaasik-Krogerus, and I. van Huis, 51-78. New York: Palgrave Macmillan.

Manners, I. 2011. “Symbolism in European Integration.” Comparative European Politics 9(3): 243-268.

Merleau-Ponty, M. 1968. The Visible And the Invisible, trans. A. Lingis. Evanston, IL: North Western University Press.

Mugerauer, R. 1985. Language and the emergence of environment. In Dwelling, Place and Environment, edited by D. Seamon and R. Mugerauer, 51-70. Dordrecht: Springer.

Niklasson, E. 2016. Funding Matters. Archaeology and the Political Economy of the Past in the EU. Stockholm Studies in Archaeology 66. Stockholm: University of Stockholm.

Niklasson, E. 2017. "The Janus-face of European heritage: Revisiting the rhetoric of Europemaking in EU cultural politics." Journal of Social Archaeology 17(2): 138-162.

Oittinen, R. 2007. 'In Hoc Signo Vinces. Eurosigns in the City Scenery of Brussels." In Media and Urban Space. Understanding, Investigating and Approaching Mediacity, edited by Frank Eckardt, 1-27. Berlin: Frank \& Timme GmbH.

Passerini, L. (ed.) 2003. Figures d'Europe: Images and Myths of Europe. Brussels: Peter Lang.

Patel, K. K. 2013. "Introduction.” In The Cultural Politics of Europe. European Capitals of Culture and European Union Since the 1980s, edited by K. K. Patel, 1-15. London: Routledge. 
Pearson, C. 2013. "EUtopia? The European Union and the Parlamentarium in Brussels." City: Analysis of Urban Trends, Culture, Theory, Policy, Action 17(5): 636-653.

Perchoc, P. 2017. "Brussels: What European Urban Narrative?" Journal of Contemporary European Studies 25(3): 367-379

Prutsch, M. J. 2013. European Historical Memory: Policies, Challenges and Perspectives. Directorate-General for Internal Policies. Policy Department B: Structural and Cohesion Policies. Culture and Education. Brussels: European Parliament.

Quinn, C. 2009. "Perception and Painting in Merleau-Ponty's Thought." Perspectives: International Postgraduate Journal of Philosophy 2(1): 38-59.

Regout, O. 2014. "3 Sections of the Berlin Wall in Brussels." Brusselslife, 6 November. Retrieved from https://www.brusselslife.be/en/article/3-sections-of-the-berlin-wall-in-brussels

Ricoeur, P. 1973. “The Hermeneutical Function of Distanciation.” Philosophy Today 17(2): $129-143$.

Ricoeur, P. 1981. Hermeneutics and the Human Sciences: Essays on Language, Action and Interpretation. Cambridge: Cambridge University Press.

Romańczyk, K. M. 2012. “Transforming Brussels into an International City? Reflections on 'Brusselization'.' Cities 29(2): 126-132.

Schorch, P. 2014. "Cultural feelings and the making of meaning." International Journal of Heritage Studies 20(1): 22-35.

Schwartz, B. 1990. "The Reconstruction of Abraham Lincoln.” In Collective Remembering, edited by D. Middleton and D. Edwards, 81-107. London: Sage. 
Seamon, D. 2000. A Way of Seeing People and Place: Phenomenology in EnvironmentBehavior Research. In Theoretical Perspectives in Environment-Behavior Research, edited by S. Wapner, J. Demick, T. Yamamoto, and H. Minami, 157-178. New York: Plenum.

Seamon, D. 2002. Phenomenology, Place, Environment and Architecture: A Review of the Literature. $\quad$ http://environment-ecology.com/environment-and-architecture/113phenomenology-place-environment-and-architecture-a-review-of-the-literature.html

Settele, V. 2015. "Including Exclusion in European Memory? Politics of Remembrance at the House of European History.” Journal of Contemporary European Studies 23(3): 405-416.

Shore, C. 1996. "Imagining the New Europe: Identity and Heritage in European Community Discourse." In Cultural Identity and Archaeology: The Construction of European Communities, edited by P. Graves-Brown, S. Jones and C. S. Gamble, 96-115. London: Routledge.

Shore, C. 2000. Building Europe. The Cultural Politics of European Integration. London: Routledge.

Shore, C. 2006. “'In uno plures': EU Cultural Policy and the Governance of Europe.” Cultural Analysis 5:7-26.

Shore, C. and S. Wright. 1997. "Policy: A New Feld for Anthropology." In Anthropology of Policy. Critical Perspectives on Governance and Power, edited by C. Shore and S. Wright, 339. London: Routledge.

Sierp, A. 2014. History, Memory, and Trans-European Identity: Unifying Divisions. New York: Routledge.

Simonÿ, C., Specht, K., Andersen, I. C., Johansen, K. K., Nielsen, C., \& Agerskov, H. 2018. “A Ricoeur-Inspired Approach to Interpret Participant Observations and Interviews." Global qualitative nursing research 5. doi:10.1177/2333393618807395 
Smith, A. 1992. "National Identity and the Idea of Europe." International Affairs 68(1): 129135.

Smith, L. 2006. Uses of Heritage. London: Routledge.

Soja, E. 1996. Thirdspace: Journeys to Los Angeles and Other Real-and-Imagined Places. Oxford: Blackwell.

Tilley, C. 1994. A Phenomenology of Landscape: Places, Paths, and Monuments. Oxford: Berg.

Theiler, T. 2005. Political Symbolism and European Integration. Manchester: Manchester University Press.

Victor, K. and A. Barnard. 2016. "Slaughtering for a Living: A Hermeneutic Phenomenological Perspective on the Well-Being of Slaughterhouse Employees." International Journal of Qualitative Studies on Health and Well-being 11. 30266. doi:10.3402/qhw.v11.30266

Weiss, G. 2002. "Searching for Europe: The Problem of Legitimisation and Representation in Recent Political Speeches on Europe.” Journal of Language and Politics 1(1): 59-83.

Wintle, M. 2004. Europa and the Bull, Europe, and European Studies: Visual Images as Historical Source Material. Amsterdam: Amsterdam University Press.

Wintle, M. 2009. The Image of Europe: Visualizing Europe in Cartography and Iconography Throughout the Ages. Cambridge: Cambridge University Press.

Yuval-Davis, N. 2004. "Borders, Boundaries and the Politics of Belonging." In Ethnicity, Nationalism and Minority Rights, edited by S. May, T. Modood, and J. Squires, 214-230. Cambridge: Cambridge University Press.

Yuval-Davis, N. 2006. "Belonging and the Politics of Belonging." Patterns of Prejudice 40(3): $197-214$. 